\title{
RELIANCE ON THE LAW OF THE CIRCUIT- A REQUIEM
}

\author{
WALTER V. SchaEFER*
}

For several years now, the notion has prevailed that each of the thirteen federal courts of appeals is entitled to determine its own construction of the federal Constitution, and of federal statutory and common law, without regard to the construction applied by other courts of appeals, and subject only to review by the Supreme Court of the United States. The result has been the development of thirteen separate legal enclaves-exactly what the judicial article of the Constitution of the United States was intended to abolish. ${ }^{1}$

The doctrine of the "law of the circuit" is understandably quite satisfactory to most of the judges of the United States courts of appeals. Every judge of every court, from justices of the peace on up, would like to have his decisions reviewed only by the Supreme Court of the United States. The doctrine has pleased most lawyers, too, because it has resulted in an enormously increased flow of litigation, as the same issue is relitigated in circuit after circuit. The doctrine has also provided attractive opportunities for forum-shopping, particularly for repeat litigants like the federal government and national corporations. For the Supreme Court of the United States the doctrine affords a pseudo-justification for deferring decisions on difficult issues while conflicting opinions accumulate in the courts of appeals. ${ }^{2}$ And for the ordinary citizen the doctrine has provided a high degree of assurance that the "law" as pronounced by the court of appeals of his circuit could be safely relied upon until the Supreme Court ruled otherwise.

Until recently, one of the assumed benefits of the doctrine of the law of the circuit was this element of reliability. That supposed advantage was nullified by the 1984 decision of the Supreme Court of the United States in United States $v$. Rodgers, ${ }^{3}$ which apparently destroyed any illu-

* Retired Justice, Supreme Court of Illinois (1951-1976); Of Counsel, Rothschild, Barry \& Myers, Chicago, Illinois.

1. The constitutional infirmity of the "Balkanization" created by the "law of the circuit" is clearly suggested by the recent regional banking decision. There the Court pointed out that regionalism, without congressional authorization under the commerce clause of the Constitution, is invalid. And the goal of article III of the Constitution is uniformity, not regionalism. See Northeast Bancorp, Inc. v. Board of Governors, 105 S. Ct. 2545, 2553-54 (1985).

2. This practice is given false legitimacy by calling it "percolation."

3. 104 S. Ct. 1942 (1984). 
sion that the decision of a court of appeals established the law that could be relied on within that circuit. The Supreme Court stated:

Finally, respondent urges . . . that because the Friedman [v. United States] case has been on the books in the Eighth Circuit for a number of years a contrary decision by this Court should not be applied retroactively to him. . . . And any argument by respondent against retroactive application to him of our present decision, even if he could establish reliance upon the earlier Friedman decision, would be unavailing since the existence of conflicting cases from other courts of appeals made review of that issue by this Court and decision against the position of the respondent reasonably foreseeable. ${ }^{4}$

In other words, no one has any right to rely on a federal circuit court of appeals decision in ordering his affairs. Not only does the reliability of a court of appeals decision vanish in the face of a conflict among the circuits, but the possibility of a future conflict robs every court of appeals decision of reliability.

United States $v$. Rodgers adds an element of urgency to the solution of the problem of conflicting court of appeals decisions. If, as appears to be the case, the Supreme Court is to be the sole source of legal doctrine upon which people can rely, something must be done to reduce the period of uncertainty. 5 Yet most of the proposed solutions to the problems created by circuit conflicts would prolong the uncertainty by interposing an additional tier of appellate review between the courts of appeals and the Supreme Court. This is true of the Freund ${ }^{6}$ and $\mathrm{Hruska}^{7}$ proposals, the proposal currently being advocated by Chief Justice Burger, ${ }^{8}$ as well

4. Id. at $1948-49$ (citing Friedman v. United States, 374 F.2d 363 (8th Cir. 1967)). The opinion's penultimate paragraph, from which this quotation is taken, consisted of three sentences. The first sentence stated both of the two final contentions advanced by Rodgers. The second sentence disposed of one of these contentions, that the "rule of lenity" in construing criminal statutes should be applied in his favor. The last sentence disposed of the contention that the statute should not be applied retroactively to him. The first omission in the excerpted quotation concerns the lenity contention, and the second concerns the disposition of the lenity issue.

5. As the Supreme Court recently pointed out, in Wilson v. Garcia, 105 S. Ct. 1938, 1947 n.34 (1985), a case construing a statute of limitations:

On a human level, uncertainty is costly to all parties. Plaintiffs may be denied their just remedy if they delay in filing their claims, having wrongly postulated that the courts would apply a longer statute. Defendants cannot calculate their contingent liabilities, not knowing with confidence when their delicts lie in repose.

6. Federal Judicial Center, Report of the Study Group on the Caseload of the SUPREME COURT, 57 F.R.D. 573, 590, 611 (1972). The Study Group is popularly known as the Freund Commission, after its chairman, Professor Paul A. Freund.

7. Commission on Revision of the Federal Court appellate System, Structure AND INTERNAL Procedures: RECOMMENDATIONS FOR CHANGE, 67 F.R.D. 195, 199, 208 (1975). The Commission is popularly known as the Hruska Commission, after its chairman, Senator Roman L. Hruska.

8. Burger, Annual Report on the State of the Judiciary, 69 A.B.A. J. 442, 447 (1983). 
as two proposals ${ }^{9}$ that have approached the problem from the perspective of citizens, who are consumers of legal doctrine, rather than from the institutional perspective of judicial administration.

Two suggestions, if adopted by the Supreme Court, would contribute substantially to the reduction of the volume of litigation and address the problem raised by Rodgers. The first is to eliminate the practice of that Court in putting off the determination of whether its decision announcing a new legal doctrine, or overruling an existing precedent, is to operate prospectively or retroactively. The propriety of limiting the effect of a judicial decision to events that take place after the decision has been formally recognized since Justice Cardozo's decision in Great Northern Railway v. Sunburst Oil and Refining Co. ${ }^{10}$ in 1932. Commentators have long agreed that the determination of prospective or retroactive operation should be made in the decision announcing the new rule:

Inconsistency between an overruling decision and subsequent cases may be eliminated if the problem is faced when the overruling case is before the court. At that time the court must consider whether the reasons in favor of overruling justify whatever confusion and hardship may be expected to result in future cases from reliance on the precedents. If the seriousness of the error is deemed to warrant an overruling notwithstanding probable hardship to present and future litigants, the overruling decision should become law for any subsequent case. ${ }^{11}$

The late Chief Justice Roger J. Traynor said that he perceived nonretroactive rulings as presenting two concomitant but distinct issues:

First, should there be a new rule? If so, the second issue would be whether to apply the new rule retroactively. Since the issue of retroactivity turns on reliance, a party who may have significantly relied on the overruled precedent is very differently situated from parties in the future who will have no comparable basis for reliance. ${ }^{12}$

Sometimes the Supreme Court has done so, as it did in Northern Pipeline Construction Co. v. Marathon Pipe Line Co., ${ }^{13}$ decided in 1982. There the Court said: "Having concluded that the broad grant of jurisdiction to the bankruptcy courts . . . is unconstitutional, we must now determine whether our holding should be applied retroactively to the ef-

9. See Coleman, The Supreme Court of the United States: Managing its Caseload to Achieve its Constitutional Purposes, 52 FordhaM L. Rev. 1, 18-19 (1983); Thompson, Increasing Uniformity and Capacity in the Federal Appellate System, 11 HASTINGS CONST. L.Q. 457, $493-94$ (1984).

10. 287 U.S. 358 (1932).

11. Note, The Effect of Overruled and Overruling Decisions on Intervening Transactions, 47 HARV. L. REv. 1403, 1413 (1934) (citations omitted).

12. Traynor, Transatlantic Reflections on Leeways and Limits of Appellate Courts, 1980 UTAH L. Rev. 255, 269; see also Schaefer, Prospective Rulings: Two Perspectives, 1982 SuP. CT. Rev. 1, 21 22.

13. 458 U.S. $50,87-88$ (1982). 
fective date of the Act." 14 Relying on Chevron Oil Co. v. Huson, ${ }^{15}$ the Court held that its decision should apply only prospectively. ${ }^{16}$ Too often, however, the Supreme Court fails to determine retroactivity or prospectivity in its law-changing decision, and instead allows that issue "to fester" in the lower courts until finally the Supreme Court reaches it years later. ${ }^{17}$

The needless litigation that is generated by putting off the determination of retroactivity is illustrated by a recent case in the United States District Court for the Northern District of Illinois. ${ }^{18}$ The issue was the retroactivity of Wilson $v$. Garcia, ${ }^{19}$ which announced a new rule governing the period of limitations for section 1983 actions filed in federal courts, but did not decide the retroactivity issue. Judge Bernard $\mathbf{M}$. Decker was confronted on the one hand with the settled rule of the Seventh Circuit, ${ }^{20}$ and on the other with the new, and different, rule announced in Wilson v. Garcia. He pointed out that conflicts as to the retroactivity of Wilson $v$. Garcia had already developed in the three months since the Court announced Wilson v. Garcia. ${ }^{21}$ He ruled in favor of prospectivity, persuaded by the circuit precedent and the inequity of a retroactive result. ${ }^{22}$ Judge Decker disposed of United States v. Rodgers on the ground that earlier decisions ${ }^{23}$ had ruled in favor of prospectivity. ${ }^{24} \mathrm{He}$ then certified the case for appeal to the Seventh Circuit Court of Appeals. ${ }^{25}$

If the Supreme Court would consistently decide at once the question of prospectivity or retroactivity as it did in the Northern Pipeline case, the remaining conflicts, resulting from conflicting constructions of constitutional or statutory provisions, could be eliminated promptly by adopting a second suggestion, which does not require legislation and involves only a modest exercise of the Supreme Court's supervisory juris-

14. Id. at 87 (citations omitted) (emphasis added).

15. 404 U.S. 97 (1971).

16. Northern Pipeline, 458 U.S. at 88.

17. The phrase "to fester" comes from Beytagh, Ten Years of Non-retroactivity: A Critique and a Proposal, 61 VA. L. Rev. 1557, 1588 (1975).

18. Moore v. Floro, 614 F. Supp. 328 (N.D. Ill. 1985).

19. 105 S. Ct. 1938,1949 (1985).

20. Beard v. Robinson, 563 F.2d 331, 338 (7th Cir. 1977), cert. denied, 438 U.S. 907 (1978).

21. Moore v. Floro, 614 F. Supp. 328, 331 n.3 (N.D. Ill. 1985) (citing Smith v. City of Pittsburgh, 764 F.2d 188, 196-97 (3d Cir. 1985); Winston v. Sanders, 610 F. Supp. 176, 179 (C.D. Ill. 1985)).

22. Moore v. Floro, 614 F. Supp. 328, $331-34$ (N.D. Ill. 1985).

23. Solem v. Stumes, 104 S. Ct. 1338, 1345 (1984); Chevron Oil Co. v. Huson, 404 U.S. 97. 107-09 (1971). Neither of these decisions involved a conflict among federal courts of appeals.

24. Moore v. Floro, 614 F. Supp. 328, 333 n.6 (N.D. Ill. 1985).

25. Moore v. Floro. No. 84 C 10824 (N.D. Ill. Aug. 5. 1985) (order granting motion to certify for interlocutory appeal). 
diction. ${ }^{26}$ As I have discussed more fully elsewhere:

By rule and decision the Supreme Court could require procedures that would sharply reduce the conflicts and increase the uniformity of national law. A Supreme Court rule could provide that the first panel decision of a court of appeals would establish the proposition for all of the courts of appeals, just as it now does for all subsequent three-judge panels within the circuit and for all of the district courts within the circuit. That decision would remain controlling until it is overruled en banc by a court of appeals, either of that or another circuit. That $e n$ banc decision would control until overruled by the Supreme Court. ${ }^{27}$

Citizens throughout the nation, regardless of circuit boundaries, would be entitled to rely on each of these decisions while it was in effect.

26. The Supreme Court has freely exercised its supervisory jurisdiction since at least as far back as McNabb v. United States, 318 U.S. 332, 340 (1943) ("Judicial supervision of the administration of criminal justice in the federal courts implies the duty of establishing and maintaining civilized standards of procedure and evidence.").

27. Schaefer, Reducing Circuit Conflicts, 69 A.B.A. J. 452, 455 (1983). 